57. Vierucci, A., DeMartino, M., London, W. T., and Blumberg, B. S.: Neutrophil function in children who are chronic carriers of hepatitis B surface antigen. Lancet, I: 157 (1977)

58. Wilkinson, P. C.: Chemotaxis and Inflammation. p. 168 (Churchill-Livingstone, Edinburgh and London, 1974).

59. Winston, D. J., Stevens, P., Lin, C. H., and Gale, R. P.: Cytomegalovirus inhibits luminol-dependent chemiluminescence of phagocytising polymorphonuclear granulocytes. Clin. Res., 29: 392A (1981).

60. Zigmond, S. H. and Hirsch, J. G.: Effects of cytochalasin B on polymorphonuclear leukocyte locomotion, phagocytosis and glycolisis. Exp. Cell Res., 73: 383 (1972).
61. All blood sample were obtained after previous informed parental consent.

62. The authors thank Mr. Sergio Nanni and Mr. Paolo Parigi for skillful technical assistance.

63. Requests for reprints should be addressed to: Baruch S. Blumberg, M.D., Institute for Cancer Research, 7701 Burholme Avenue, Philadelphia, PA, 19111 (USA)

64. This study was in part supported by grant number 80.00605 .04 from the Italian Consiglio Nazionale delle Ricerche and by USPHS grants CA-06551, RR05539 and CA-06927 from the National Institutes of Health and by an appropriation from the Commonwealth of Pennsylvania.

65. Received for publication March 4, 1982.

66. Accepted for publication March 10, 1983.

\title{
Neutrophil and T Lymphocyte Characteristics of Two Patients with Hyper-IgE Syndrome
}

\author{
MARGARET SODERBERG-WARNER, CAROL A. RICE-MENDOZA, GUILLERMO R. MENDOZA, ${ }^{(58)}$ \\ AND E. RICHARD STIEHM \\ Division of Immunology/Allergy, Department of Pediatrics and the Center for Interdisciplinary Research in \\ Immunologic Disease, UCLA Medical Center, Los Angeles, California, USA
}

\section{Summary}

Immunologic parameters including quantitative and qualitative immunoglobulin studies, various $T$ cell functions and neutrophil chemotaxis were evaluated in two patients with the Hyper-IgE syndrome. Both exhibited pruritic dermatitis in locations atypical for atopic dermatitis, marked elevations in serum IgE levels (to $40,000 \mathrm{IU} / \mathrm{ml}$ ), recurrent staphylococcal abscesses, coarse facial features and variable chemotactic defects characteristic of this syndrome. Both patients responded favorably to courses of trimethoprim-sulfamethoxazole, particularly in helping control the cutaneous infections. We believe that this is a useful therapeutic alternative to anti-staphylococcal antibiotics and prophylactic treatment has permitted therapeutic response.

Serum IgG, IgG subclasses, IgM, and IgA were normal for age. Serum IgD was markedly deficient in one patient. Functional IgM was normal with positive isohemagglutinin titers. IgG poliovirus titers were present in both patients; however, tetanus titers were not detectable in either patient, despite repeated immunizations.

Despite normal $\mathbf{E}$ rosette numbers, subtle $\mathbf{T}$ cell abnormalities were noted with variable responses to both in vivo SK-SD, candida, and mumps skin tests and in vitro PHA-, Con A-tetanus-induced lymphocyte proliferation. Lymphocyte production of macrophage inhibitory factor and interferon and responsiveness in a mixed lymphocyte culture were normal in both patients. Considerable Con-A-induced suppressor cell activity was present in one patient, but diminished in the other.

In vivo chemotaxis determined by a Rebuck skin window, revealed a markedly delayed PMN migration in both patients during a time when both patients were clinically free of furunculosis or dermatitis. In vitro neutrophil chemotaxis was variable: maximally impaired in one patient during severe pneumonia and normalizing with clinical resolution; the low chemotactic activity of the second patient did not consistently correspond to the clinical state.

Both patients demonstrated high serum histamine levels of 75 $100 \mathrm{ng} / \mathrm{ml}$ (normal $<1 \mathrm{ng} / \mathrm{ml}$ ). The neutrophils of 8 of 11 normal adults showed significantly enhanced chemotaxis (26-52\%) in the presence of $10^{7}$ to $10^{4} \mathrm{M}$ histamine, and comparable enhancement with the same concentrations of the $\mathrm{H}_{2}$ antagonist, cimetidine (1738\%). Both histamine and cimetidine consistently depressed chemotaxis in one patient. The other patient had enhanced chemotaxis in the presence of histamine and an inconsistent response to cimetidine. Histamine and cimetidine may affect neutrophils directly via $\mathrm{H}_{2}$ receptors, indirectly via $\mathrm{H}_{2}$ feedback inhibition of basophil histamine release or by non- $\mathrm{H}_{2}$ mechanisms.

\section{Abbreviations}

CBC, complete blood count

CGD, chronic granulomatous disease

MIF, migration inhibition factor

MLC, mixed leukocyte culture

PHA, phytohemagglutin

PMN, polymorphonuclear leukocytes

Immunologic function, including quantitative and qualitative immunoglobulin studies, various $T$ cell functions and neutrophil chemotaxis was evaluated in two patients with the Hyper-IgE syndrome $(6,9,16)$. Both exhibited pruritic dermatitis, marked elevations in serum IgE levels (to $40,000 \mathrm{IU} / \mathrm{ml}$ ), recurrent staphylococcal abscesses, coarse facial features, variable chemotactic defects and $T$ cell defects characteristic of this syndrome $(6,9,11$, $12,14,16,18,23,24,27,28,53,55)$. Additionally we report a favorable therapeutic response to trimethoprim-sulfamethoxazole, similar to that reported in CGD (33).

\section{PATIENTS}

Case 1. BB is a 20-year-old white female with a history of recurrent staphylococcal skin abscesses beginning in the first 2 weeks of life. As an infant she developed recurrent sinusitis and 
otitis media requiring myringotomies and bilateral mastoidectomies.

She was first admitted to UCLA in December 1974, for surgical correction of spondylolisthesis; coincidentally eczematoid lesions and pustules were noted over the extremities and on the ears. Routine immunologic studies were normal with the exception of an IgE level of $40,000 \mathrm{IU} / \mathrm{ml}$. A large thymus was noted by chest $\mathrm{x}$-ray and was biopsied in March 1975 to exclude thymona. Histologic studies were normal with negative immunoflourescence for IgG, IgM, IgA, and C3.

Over the following 2 years the patient was hospitalized twice for treatment of discitis and a right upper lobe pneumonia complicated by a large pneumatocele. Both infections were successfully treated with anti-staphylococcal antibiotics despite negative cultures for Staphylococcal organisms. The pneumatocele diminished in size and finally was removed surgically. The patient has continued to have recurrent abscesses of the right forearm, ankles, and pinnae of both ears.

In February 1976, the patient was placed on continuous rotating antibiotics consisting of lincomycin, cephalexin, dicloxacillin and cloxacillin at 2-3 month intervals. The furuncles would improve after each change of antibiotic, then worsen, requiring a new antibiotic. Skin cultures taken with each exacerbation were almost always positive for Staphylococcus aureus.

Because of gastrointestinal intolerance to prolonged anti-staphylococcal drugs, the patient was begun on trimethoprim-sulfamethoxazole for periods as long as 6 months. This therapy was consistently associated with rapid clearing and healing of all skin lesions. Relapse occurred on two occasions when the trimethoprim-sulfamethoxazole was stopped. The skin cultures with each flare up consistently grew Staphylococcus aureus.

Case 2. JB is a 5-year-old white female who was first hospitalized at UCLA in June 1976 to exclude chronic mucocutaneous candidiasis. She presented with a 5-year history of recurrent superficial abscesses over the face, neck, axillae, and diaper areas accompanied by recurrent thrush, Candida vaginitis and fingernail hyperkeratosis. An IgE level was $3700 \mathrm{IU} / \mathrm{ml}$. Skin cultures yielded coagulase-positive Staphylococcal aureus and oral scrapings grew Candida albicans, which responsed to oxacillin and nystatin, respectively.

Over subsequent months the patient developed recurrent otitis media and periodic exacerbations of eczema, mainly localized to the scalp, axillae, and the back of the ear. In February 1977 the patient developed right lower lobe pneumonia. Staphylococcal aureus was cultured from an open lung biopsy. Postoperative recovery was complicated by recurrent pneumothoracies and an extensive right-sided pneumatocele which responded to $4 \mathrm{wk}$ of oxacillin. Since that time she has had recurrent facial and scalp furunculosis, chronic pansinusitis, a recurrent right lower lobe pnemonia that has responded to oxacillin, and chronic pruritic dermatitis in the axillae.

In March 1976, the patient was placed on continuous oral antibiotic therapy including erythromycin and dicloxacillin. She first received trimethoprim-sulfamethoxazole in July 1977 after a pustule was culture-positive for Staphylococcus aureus, and remained on it for twelve months. After discontinuation of the antibiotic because of a finding of neutropenia on a periodic CBC evaluation, the furunculosis recurred; however, upon resumption of the drug, 2 wk later, the patient's skin lesions rapidly cleared. No pulmonary lesions have reoccurred.

\section{MATERIALS AND METHODS}

Informed consent was obtained for both study group and control subjects. Unless otherwise noted, the two patients were afebrile, experiencing a stable course and without evidence of acute infectious episodes.

$\mathrm{IgG}, \operatorname{IgM}$, and $\mathrm{IgA}$ were quantitatively determined by radial immunodiffusion (17). IgE levels were performed by a direct radioimmunoassay (PRIST; Pharmacia; Piscataway, NJ) (10). Antibody titers $(25,50)$, lymphocyte enumeration for $\mathrm{B}(25)$ and $\mathrm{T}$ cells (29), PHA and Candida proliferative responses (38), mixed leukocyte culture (22), and HLA typing (51) were done by standard immunologic methods. MLCs were run using the patient's cells as responders with stimulator cells obtained from both parents and two unrelated donors.

In vivo chemotaxis. The Rebuck skin window method (42) was used to determine chemotaxis. The patient's skin was abraded with a scalpel blade superficially over an area of $4 \mathrm{~mm}$, and cover slips were placed over the site. The slips were changed in this experiment three times every $2 \mathrm{~h}$, then every $4 \mathrm{~h}$ during the first 24-h period. The slides were then stained and analyzed.

In vitro chemotaxis. Activated serum, the chemotactic factor, was prepared by incubating $50 \mathrm{mg}$ zymosan (Sigma Chemical Co.; St. Louis, MO) in $1 \mathrm{ml}$ human serum from a healthy donor for 30 min at $37^{\circ} \mathrm{C}$. The mixture was centrifuged at $2000 \times g$ at $4^{\circ} \mathrm{C}$ for $10 \mathrm{~min}$ to remove insoluble materials, incubated at $56^{\circ} \mathrm{C}$ for an additional $30 \mathrm{~min}$, and stored at $-20^{\circ} \mathrm{C}$.

Peripheral blood leukocytes were assayed for neutrophil chemotaxis under agarose as described by Nelson et al (41). Heparinized blood was mixed 85:15 with Plasmagel (HTI Corporation, Buffalo, NY) and the cells were allowed to settle for 15-20 min. The top layer of cells was washed with $100 \mathrm{ml} 0.9 \% \mathrm{NaCl}$ and centrifuged at $190 \times g$ for $8 \mathrm{~min}$. The wash step was repeated twice with $10 \mathrm{ml}$ normal saline. The neutrophils were counted and resuspended at $2.5 \times 10^{6}$ cells/ml in RPMI medium (M.A. Bioproducts, Walkersville, $\mathrm{MD}$ ). In some experiments the cells were preincubated for $1 \mathrm{~h}$ at $37^{\circ} \mathrm{C}$ with $10^{-7}$ to $10^{-4} \mathrm{M}$ histamine dihydrochloride (Sigma) or $10^{-7}$ to $10^{-4} \mathrm{M}$ cimetidine- $\mathrm{HCl}$ (a gift from Smith, Kline \& French Laboratories; Philadelphia, PA), a selective $\mathrm{H}_{2}$ antagonist.

After preincubation in either control RPMI buffer or different concentrations of histamine or cimetidine, the cells were resuspended and tested for chemotaxis under agarose in $35 \times 10 \mathrm{~mm}$ polystyrene tissue culture dishes (\#3001; Falcon Plastics; Oxnard, CA). Three 4-mm wells were punched through the agarose across the diameter of each plate. The center well contained $10 \mu \mathrm{l}$ of cells at $2.5 \times 10^{6}$ cells $/ \mathrm{ml}$, with $10 \mu \mathrm{l}$ of activated human serum occupying one outer well and $10 \mu 1$ of normal saline in the opposite outer well. All chemotaxis plates were set up in triplicate. After a 3 -h incubation at $37^{\circ} \mathrm{C}$ in a humidified $\mathrm{CO}_{2}$ incubator, chemotaxis was determined microscopically by counting the number of cells moving toward the chemotatic factor minus the number of cells spontaneously moving toward the normal saline. The results are expressed in terms of the mean \% increase or decrease in movement of histamine- or cimetidine-pretreated cells compared to control migration.

Lymphocyte mediators. Lymphocyte cultures were stimulated with PHA, tetanus or candida. Interferon- $\gamma$ in PHA supernatants was determined by means of a micro-dye uptake of human trisomy 21 cells after virus challenge with encephalomyocarditis virus (5). Macrophage inhibitory factor (MIF) was assessed by inhibition of normal adult mononuclear cell migration under agarose, utilizing supernatants obtained by stimulating Ficoll-Hypaque separated mononuclear cells with PHA, Candida, or tetanus for $48 \mathrm{~h}(56)$.

Suppressor cells. $\mathrm{T}$ suppressor cells were analyzed by a modification of the original assay of Shou et al. (47), described by Horowitz et al. (26). Briefly, $1 \times 10^{6}$ patient cells to be used as suppressors were incubated with buffer or $20 \mu \mathrm{g}$ of Con A for 48 $\mathrm{h}$, irradiated, and added $1 \times 10^{6}$ Adult A responder cells plus 1 $\times 10^{6}$ adult $\mathrm{B}$ irradiated stimulator cells. Tritiated thymidine uptake was assessed after 5 days of incubation. Suppression was calculated by the formula:

$$
\begin{gathered}
\% \text { Suppresion }=[(\text { Control CPM }- \text { Experimental CPM } / \text { Control } \\
\text { CPM }] \times 100
\end{gathered}
$$

[Control CPM, counts obtained by incubating Adult A responder cells with Adult B irradiated (non-Con A stimulated) stimulator cells for 5 days, i.e., the MLC alone and Experimental CPM, counts obtained by adding Con A-stimulated patients cells to the MLC reaction). Suppressor cell-induced diminution of MLC proliferation is expressed as a negative number. 
Table 1. Immunologic features of two hyper-IgE patients

\begin{tabular}{|c|c|c|}
\hline & $\begin{array}{c}\text { BB (age, } 20 \\
\text { years) }\end{array}$ & JB (age, 5 years) \\
\hline \multicolumn{3}{|l|}{ Immunoglobulins } \\
\hline $\operatorname{IgG}$ & $1300 \mathrm{mg} / \mathrm{dl}$ & $730 \mathrm{mg} / \mathrm{dl}$ \\
\hline IgG subclasses & Normal & Normal \\
\hline IgM & $170 \mathrm{mg} / \mathrm{dl}$ & $65 \mathrm{mg} / \mathrm{dl}$ \\
\hline $\operatorname{IgA}$ & $260 \mathrm{mg} / \mathrm{dl}$ & $56 \mathrm{mg} / \mathrm{dl}$ \\
\hline IgD & $8 \mathrm{mg} / \mathrm{dl}$ & $0 \mathrm{mg} / \mathrm{dl}$ \\
\hline IgE & $44,000 \mathrm{IU} / \mathrm{ml}$ & $4000-10,600 \mathrm{IU} / \mathrm{ml}$ \\
\hline \multicolumn{3}{|l|}{ Functional antibodies } \\
\hline Isohemagglutinins & $1: 8$ & $1: 8$ \\
\hline Poliovirus & (+) $1: 16$ & (+) $1: 16$ \\
\hline Tetanus & $(-) 1: 2$ & $(-) 1: 2$ \\
\hline \multicolumn{3}{|l|}{ Cellular immunity } \\
\hline E rosettes & $62 \%$ & $65 \%$ \\
\hline \multicolumn{3}{|l|}{ Delayed skin tests } \\
\hline & (+) Candida & $(+/-)$ Candida \\
\hline & (+) SK-SD & (-) SK-SD \\
\hline & (+) Mumps & (-) Mumps \\
\hline & (-) Tetanus & (-) Tetanus \\
\hline \multicolumn{3}{|l|}{ Lymphocyte proliferation } \\
\hline & (+) $\mathrm{PHA}^{1}$ & (+) PHA \\
\hline & $(+) \mathrm{MLC}^{2}$ & $(+/-) \mathrm{MLC}$ \\
\hline & $(+)$ Candida & (-) Candida \\
\hline & (+) Tetanus & $(+)$ Tetanus \\
\hline \multicolumn{3}{|l|}{ Lymphokines } \\
\hline MIF & Normal & Normal \\
\hline Interferon- $\gamma$ & Normal & Normal \\
\hline T suppressor activity ${ }^{3}$ & $5 \% \pm 7$ & $89 \% \pm 11$ \\
\hline \multicolumn{3}{|l|}{ In vitro chemotaxis } \\
\hline Neutrophili (\% normal ${ }^{4}$ ) & $45 \pm 12 \%^{5}$ & $74 \pm 37 \% \%^{6}$ \\
\hline $\begin{array}{l}{ }^{1} \text { Normal stimulation ind } \\
{ }^{2} \text { Normal stimulation ind } \\
{ }^{3} \text { Normal is } 25-80 \% \text { inhik } \\
{ }^{4} \text { Migration compared to } \\
{ }^{5} n=3 \text {. } \\
{ }^{6} n=2 .\end{array}$ & $\begin{array}{l}>25 \text { (stimulated } \\
>10 \text { (stimulated } \\
\text { of the control } \mathrm{N} \\
\text { ol cells run on s }\end{array}$ & $\begin{array}{l}\text { ontrol). } \\
\text { ontrol). } \\
\text { C. } n=2 \text { in each study. } \\
\text { e day. }\end{array}$ \\
\hline
\end{tabular}

\section{RESULTS}

Immunologic studies. Table 1 summarizes the immunologic studies performed on the two hyper-IgE patients. Serum IgG, including all IgG subclasses, IgM, and IgA were normal for age. Serum IgD was non-detectable by radial diffusion in one patient. Functional IgM was normal with positive isohemagglutinin titers. Normal poliovirus titers were present in both patients; however tetanus titers were not detectable in either patient, despite repeated booster injections.

Despite normal $\mathrm{E}$ rosette numbers, subtle $\mathrm{T}$ cell abnormalities were noted in both patients. Patient BB was consistently anergic to tetanus toxoid despite a positive in vitro proliferative response to tetanus antigen. She also demonstrated diminished suppressor cell activity on two occasions. Patient JB was anergic to all skin test antigens, except on one occasion, she had a weak response to candida antigen. In the MLC reaction, her lymphocytes were not stimulated by her father's leukocytes, but were stimulated by her mother's leukocytes and two unrelated donors. Her lymphocytes did not proliferate to candida or tetanus antigens despite known antigen exposure.

Chemotactic studies. In vivo chemotaxis was determined by a Rebuck skin window and revealed a markedly delayed PMN migration in both patients during a time when both patients were free of furunculosis and dermatitis.

In vitro neutrophil chemotaxis was consistently impaired in patient $\mathrm{BB}$, especialy during severe infections, with increasing, yet low values with clinical resolution. The chemotactic activity of patient JB were variable and did not consistently correspond to the clinical state. Neutrophil chemotactic values for both patients were determined on days when the patients were free of infection and had not received antibiotics or antihistamines for $72 \mathrm{~h}$ (see Table 1).

On infection-free days both patients demonstrated high serum histamine levels of $75-100 \mathrm{ng} / \mathrm{ml}$ (normal $<1 \mathrm{ng} / \mathrm{ml}$ ) on three separate determinations. Accordingly, as shown in Figure 1 chemotaxis was restudied after neutrophil preincubation with histamine or the $\mathrm{H}_{2}$ antagonist, cimetidine. Mean baseline migrations for eight normal adults and patient $\mathrm{BB}$ from triplicate determinations were as follows: adult controls $(328 \pm 130, n=11)$ and patient $\mathrm{BB}(136 \pm 23, n=3)$. These numbers represent migration of about $10 \%$ of the total cells from the center well. In all experiments less than 10 cells were counted moving toward the buffer control well (data not shown); thus, there was no evidence of increased random movement (chemokinesis) with either drug (data not shown). Eight of 11 normal adult neutrophil studies showed significantly elevated chemotaxis (26-52\%) with cells preincubated in $10^{-7}$ to $10^{-4} \mathrm{M}$ histamine, and comparable enhancement with the same concentrations of the $\mathrm{H}_{2}$ antagonist, cimetidine (17-38\%). Three of the 11 normal adult controls showed no significant change in chemotaxis at any concentration of either drug (data not shown). Cimetidine depressed chemotaxis in patient $\mathrm{BB}$ in three separate studies (32-67\%); histamine also depressed migration in the same experiments (12-34\%). Neutrophils from patient JB were restudied on a single occasion. Whereas previous studies had shown reduced chemotaxis, on this day chemotaxis was greater than the control; moreover, there was a $33-76 \%$ enhancement of chemotaxis with $10^{-7}$ to $10^{-4} \mathrm{M}$ histamine. Responses to cimetidine in JB were variable with both enhancement and inhibition at different concentrations of the drug (data not shown).

\section{DISCUSSION}

The immunologic defects that lead to the chronic infections in the Hyper-IgE syndrome are not yet established. Many immunologic disturbances have been identified but none are consistent or pathognomonic. The IgD deficiency present in patient JB is a new finding in the Hyper-IgE syndrome. Normal (6) and elevated IgD levels (7) have previously been reported in these patients. A selective IgD immunodeficiency has been reported in some pa-

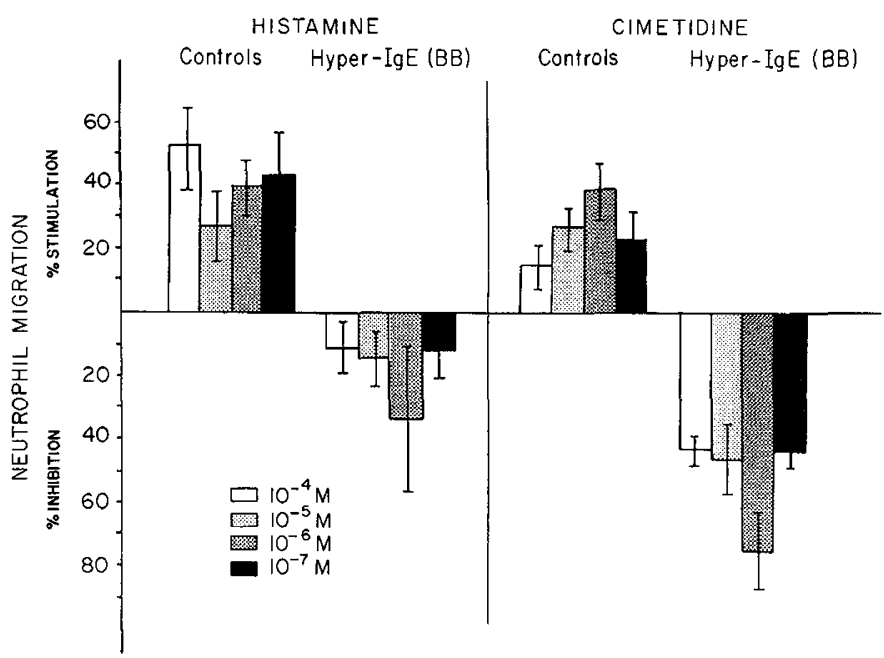

Fig. 1. Comparison between neutrophil chemotaxis in eight normal adults and patient BB with hyper-IgE syndrome. Neutrophils were preincubated in buffer or different concentrations of histamine or cimetidine for $1 \mathrm{~h}$ before migration assay. Results are expressed in mean \% enhancement or inhibition of migration of experimental cells compared to buffer control cells. The results of migration with patient BB represent means from triplicate determinations on three different days. See text for results of chemotaxis with patient JB. 
tients with the Wiskott-Aldrich syndrome and in some patients with a selective IgA deficiency (7).

The production of $\operatorname{IgE}$ antibodies to Staphylococcal antigens may relate directly to the unique patterns of infections seen in Hyper-IgE patients $(2,45)$. Protein A from Staphylococcus aureus is a potent B cell mitogen (19), and may contribute to the exaggerated $\operatorname{IgE}$ response seen in these patients. The association of $T$ cell abnormalities and enhanced $\operatorname{IgE}$ synthesis is apparent in several other human immunodeficiencies; these include the Wiskott-Aldrich syndrome (3), Nezelof's syndrome (32), and selective IgA deficiency in some patients (54). In the present study, variable $\mathrm{T}$ cell abnormalities were observed in one or both patients, including enlarged thymus, cutaneous anergy, failure of response in an MLC, and diminished suppressor T cells.

A selective deficiency of $\mathrm{T} 8+$ suppressor $\mathrm{T}$ cells has been described in patients with the Hyper-IgE syndrome (20) and may be a primary factor in the regulation of $\operatorname{IgE}$ synthesis $(8,36,44)$ in the Hyper-IgE syndrome. The subnormal Con-A-induced suppressor activity described in one patient in this report has been previously reported in the Hyper-IgE syndrome $(20,30)$; moreover, intermittent or chronic local elevations of histamine on various targets, including $\mathrm{T}$ lymphocytes, may exacerbate an inherent regulatory abnormality. Indeed there is evidence that histamine may bind to $\mathrm{H}_{2}$ receptors on $\mathrm{T}$ lymphocytes and may either inhibit (46) or promote (15) T cell suppressor activity.

Serial determinations of in vitro neutrophil chemotaxis gave variable results and the chemotactic defects did not correlate with the presence or absence of infection. Whereas in vivo neutrophil migration was diminished in both patients, only patient BB manifested a consistent chemotaxis defect in vitro with $\mathrm{C} 5 \mathrm{a}$.

Histamine levels of $75-100 \mathrm{ng} / \mathrm{ml}$ were noted in both patients described herein. In addition, basophils from both patients regularly demonstrated greater than $25 \%$ spontaneous release of histamine in vitro. The occurrence of abnormal neutrophil chemotaxis with the Hyper-IgE syndrome could be related to chronic basophil or mast cell degranulation.

In this study, histamine enhanced neutrophil migration in control subjects yet further depressed the low neutrophil chemotaxis in patient BB. Histamine had variable effects on the chemotaxis of the other patient which were not statistically significant (data not shown). Previous work by others has shown that histamine may augment neutrophil chemotaxis either directly or indirectly by the production of $\mathbf{T}$ lymphocyte-derived factor counteracting leucocyte inhibition factor (43). Histamine has also been shown to inhibit neutrophil chemotaxis $(1,23)$ and basophil chemotaxis $(35)$ in normal adults, but this effect was not shown in another report (49). Biphasic effects have been described with eosinophils, with augmentation and inhibition of migration at low and high concentrations of histamine, respectively (13).

The effects of cimetidine on control neutrophil migration were identical to histamine. Cimetidine has been shown to block feedback inhibition of histamine release in human basophils (52) and has been used in the treatment of patients with Hyper-IgE syndrome with apparent benefit (39). Surprisingly, the effects of cimetidine on control neutrophil migration were identical to histamine. Further studies are needed to better understand the actions of this drug on neutrophil migration. We suspect that cimetidine may have either antagonist or agonist effects on $\mathrm{H}_{2}$ receptors in different cells, inasmuch as cimetidine can be shown to inhibit degranulation, and not block feedback inhibition of histamine release in rat mast cells (40). Because neutrophil chemotaxis in only one of two patients with the Hyper-IgE syndrome could be restudied in detail with respect to the effects of histamine and cimetidine, the potential implications of the observed inhibitory effects of histamine and cimetidine on neutrophils with abnormal migration will require confirmation by further studies with other patients with chemotactic defects.

The neutrophil preparations used in this study contained between 1-5\% basophils. Their presence is not generally considered a factor in the interpretation of migration assays; however, C5a is the principal neutrophil attractant in zymosan-activated serum
(31) and also a known trigger for both basophil chemotaxis (34) and degranulation $(21,48)$. Numerous basophil mediators, including histamine, could directly or indirectly either enhance or inhibit normal C5a-induced neutrophil chemotaxis. The effect of mediators on neutrophils with abnormal migration is evident; the release of endogenous histamine from basophils could have direct inhibitory or enhancing effects on co-migrating neutrophils. Furthermore, the interpretation of endogenous $\mathrm{H}_{2}$ receptor stimulation on basophils and neutrophils would be further complicated by the experimental addition of exogenous histamine and cimetidine, which could either directly affect neutrophil migration or indirectly disturb feedback inhibition of basophil degranulation $(4$, $25,37,52)$.

In summary, there is evidence for abnormal regulatory $\mathrm{T}$ cell functions in the Hyper-IgE syndrome. The ubiquity of the histamine receptor in various immunologic cells, including $\mathrm{T}$ suppressor cells, neutrophils, mast cells, and basophils, suggests that chronic histamine release could secondarily interfere with immunoregulation and perpetuate a selective immunodeficiency. The immunologic effects of histamine are likely to be complex, reflecting the interaction of different histamine receptor-bearing immune cells with normal or altered responsiveness to histamine; moreover, individual cells may show biphasic or opposite physiologic effects at low and high concentrations of histamine. The aggressive use of combined $\mathrm{H}_{1}$ and $\mathrm{H}_{2}$ histamine antagonists in the primary treatment of the Hyper-IgE syndrome remains a promising but, as yet, unproven approach. The mainstay of treatment of this disorder is intermittent or continuous antibiotics. If antistaphylococcal antibiotics are ineffective or poorly tolerated, the use of trimethoprim-sulfamethoxazole is recommended both in the treatment and the prevention of staphylococcal cutaneous infection. Blood counts should be periodically done to recognize the early development of drug-induced neutropenia.

\section{REFERENCES AND NOTES}

1. Anderson, R., Glover, A., and Rabson, A. R.: The in vitro effects of histamine and metiamide on neutrophil motility and their relationship to intracellular cyclic nucleotide levels. J. Immunol., 118: 1690 (1977).

2. Berger, M., Kirkpatrick, C. H., Goldsmith, P. K., and Gallin, J. I.: IgE antibodies to Staphylococcus aureus and Candida albicans in patients with the syndrome of hyperimmunoglobulin E and recurrent infections. J. Immunol., 125: 2437 (1980).

3. Berglund, G., Finnstrom, O., Johansson, S. G. O., and Moller, K. L.: WiskottAldrich syndrome. A study of 6 cases with determination of the immunoglobulins A, D, G, M, and ND. Acta Paediatr. Scand., 57: 89 (1968).

4. Bourne, H. R., Melmon, K. L., and Lichtenstein, L. M.: Histamine augments leukocyte adenosine $3^{\prime}, 5^{\prime}$-monophosphate and blocks antigenic histamine release. Science, 173: 743 (1971)

5. Bryson, Y. J., Winter, H. S., Gard, S. E., Fischer, T. J., and Steihm, E. R.: Deficiency of immune interferon production by leukocytes of normal newborns. Cell. Immunol., 55: 191 (1980).

6. Buckley, R. H., Wray, B. B., and Belmaker, E. Z.: Extreme hyperimmunoglobulinemia $E$ and undue susceptibility to infection. Pediatrics, 49: 59 (1972).

7. Buckley, R. H. and Fiscus, S. A.: Serum IgD and IgE concentrations in immunodeficiency diseases. J. Clin. Invest., 55: 157 (1975).

8. Buckley, R. H. and Becker, W. G.: Abnormalities in the regulation of human IgE synthesis. Immunol. Rev., 41: 288 (1978).

9. Buckley, R. H. and Sampson, H. A.: The hyperimmunoglobulinemia E syndrome. In: E. C. Franklin, (Ed): Clinical Immunology Update. pp. 147-167 (Elsevier, New York, 1981)

10. Ceska, M. and Lundkuist, U.: A new and simple radioimmunoassay method for the determination of IgE. Immunochemistry, 9: 1021 (1972).

11. Church, J. A., Frenkel, L. D., Wright, D. G., and Bellanti, J. A.: T lymphocyte dysfunction, hyperimmunoglublinemia $\mathrm{E}$, recurrent bacterial infections, and defective neutrophil chemotaxis in a Negro child. J. Pediatr. 88: 982 (1976).

12. Clark, R. A., Root, R. K., Kimball, H. R., and Kirkpatrick, C. H.: Defective neutrophil chemotaxis and cellular immunity in a child with recurrent infections. Ann. Intern. Med., 78: 515 (1973).

13. Clark, R. A. F., Sandler, J. A., Gallin, J. I., and Kaplan, A. R.: Histamine modulation of eosinophil migration. J. Immunol., 118: 137 (1977)

14. Dahl, M. V., Greene, W. H., and Quie, P. G.: Infection, dermatitis, increased IgE and impaired neutrophil chemotaxis. Arch. Dermatol., 112: 1387 (1976).

15. Damle, N. K. and Gupta, S.: Autologous mixed lymphocyte reaction in man. II. Histamine-induced suppression of the autologous mixed lymphocyte reaction by $\mathrm{T}$-cell subsets defined with monoclonal antibodies. J. Clin. Invest. 1: 241 (1981).

16. Davis, S. D., Schaller, J., and Wedgwood, R. J.: Job's syndrome: recurrent "cold," staphylococcal abscesses. Lancet 1: 1013 (1966).

17. Fahey, J. L. and McKelvey, E. M.: Quantitative determination of serum immu- 
noglobulins in antibody-agar plates. J. Immunol., 94: 84 (1965).

18. Fontan, G., Lorente, F., Rodriguez, M. C. G., and Ojeda, J. A.: Defective neutrophil chemotaxis and hyperimmunoglobulinemia E-a reversible defect? Acta Paediatr. Scand., 65: 509 (1976).

19. Forsgren, A., Svedjelund, A., and Wigzell, H.: Lymphocyte stimulation by protein A of Staphylococcus aureus. Europ. J. Immunol., 6: 207 (1976)

20. Geha, R. S., Reinherz, E., Leung, D., McKee, Jr., K. T., Schlossman, S., and Rosen, F. S.: Deficiency of suppressor $\mathrm{T}$ cells in the Hyperimmunoglobulin E syndrome. J. Clin. Invest., 68: 783 (1981).

21. Grant, J. A., Dupree, E., Goldman, A. S., Schultz, D. R., and Jackson, A. L.: Complement-mediated release of histamine from human leukocytes. J. Immunol., 114: 1101 (1975).

22. Hartzman, R. J., Segall, M., Bach, M. L., and Bach, F. H.: Histocompatibility matching. VI. Miniaturization of the mixed leukocyte culture test: a preliminary report. Transplantation, 11: 268 (1971)

23. Hill, H. R., Quie, P. G., Pabst, H. F., Ochs, H. D., Clark, R. A., Klebanoff, S. J., and Wedgwood, R. J.: Defect in neutrophil granulocyte chemotaxis in Job's Syndrome of recurrent "cold" staphylococcal abscesses. Lancet, 2: 617 (1974).

24. Hill, H. R., Estensen, R. D., Hogan, N. A., and Quie, P. G.: Severe staphylococca disease associated with allergic manifestations, hyperimmunoglobulinemia $\mathrm{E}$ and defective neutrophil chemotaxis. J. Lab. Clin. Med., 88: 796 (1976).

25. Hong, R.: Immunodeficiency. In: N. R. Rose and H. Friedman, (Eds.): Manual of Clinical Immunology. pp. 620-636 (American Society for Microbiology, Washington, DC, 1980).

26. Horowitz, S., Borcherding, W., Moorthy, A. V., Chesney, R., Schulte-Wissermann, H., and Hong, R: Induction of suppressor $T$ cells in systemic lupus erythematosus by thymosin and cultured thymic epithelium. Science, 197: 999 (1977).

27. Issekutz, A. C., Lee, K. Y., and Biggar, W. D.: Neutrophil chemotaxis in two patients with recurrent staphylococcal skin infections and hyperimmunoglobulinemia E. J. Lab. Clin. Med., 92: 640 (1978).

28. Jacobs, J. C. and Norman, M. E.: A familial defect of neutrophil chemotaxis with asthma, eczema, and recurent skin infection. Pediatr. Res., 11: 732 (1977).

29. Jondal, M., Holm, G., and Wigzell, H.: Surface markers on human T and B lymphocytes. I. A large population of lymphocytes forming nonimmune rosettes with sheep red blood cells. J. Exp. Med., 136: 207 (1972).

30. Katona, I. M., Tata, G., Scanlon, R. T., and Bellanti, J. A.: Hyper-IgE syndrome: a disease with suppressor T cell deficiency. Ann. Allergy, 45: 295 (1980).

31. Kay, A. B. and Austen, K. F.: Chemotaxis of human basophil leukocytes. Clin Exp. Immunol., 11: 557 (1972).

32. Kikkawa, Y., Kamimura, K., Hamajima, T., Sekiguchi, T., Kawai, T.,Takenaka, M., and Tada, T.: Thymic alymphoplasia with hyper-IgE-globulinemia. Pediatrics, 51: 690 (1973)

33. Kobayashi, Y., Amano, D., Kazuhiro, U., Kagosaki, Y., and Usui, T.: Treatment of 7 cases of chronic granulomatous disease with sulfamethoxazole-trimethoprim (SMX-TMP). Eur. J. Pediatr., 127: 247 (1978).

34. Lett-Brown, M. A., Boetcher, D. A., and Leonard, D. A.: Chemotactic responses of normal human basophils to C5a and to lymphocyte-derived chemotactic factor. J. Immunol., 117: 246 (1976).

35. Lett-Brown, M. A. and Leonard, E. J.: Histamine-induced inhibition of normal human basophil chemotaxis to C5a. J. Immunol., 118: 815 (1977)

36. Leung, D. Y. M., Rhodes, A. R., Geha, R. S.: Enumeration of T cell subsets in atopic dermatitis using monoclonal antibodies. J. Allergy Clin. Immunol., 67: 450 (1980)

37. Lichtenstein, L. M. and Gillespie, E.: Inhibition of histamine release by histamine controlled by $\mathrm{H}_{2}$ receptor. Nature, 244: 287 (1973).

38. Lucas, Z. J.: Pyrimidine nucleotide synthesis: regulatory control during transformation of lymphocytes in vitro. Science 156: 1237 (1967).

39. Mawhinney, H., Killen, M., Fleming, W. A., and Roy, A. D.: The hyperimmunoglobulin E syndrome-a neutrophil chemotactic defect reversible by histamine $\mathrm{H}_{2}$ receptor blockade? Clin. Immunol. Immunopathol., 17: 483 (1980).
40. Mendoza, G. R. and Orner, F. B.: Direct effects of histamine, cimetidine, and metiamide on rat mast cell histamine release. (unpublished data).

41. Nelson, R. D., Quie, P. G., Simmons, R. L.: Chemotaxis under agarose: new and simple method for measuring chemotaxis and spontaneous migration of human polymorphonuclear leukocytes and monocytes. J. Immunol., 115: 1650 (1975).

42. Rebuck, J. W. and Crowley, J. H.: A method of studying leukocytic functions in vivo. Ann. N.Y. Acad. Sci., 59: 757 (1955).

43. Rigal, D., Monier, J. C., and Souweine, G.: The effect of histamine on leukocyte migration test in man. I. Demonstration of a LIF production inhibitor (LIFPI). Cell. Immunol., 46: 360 (1979).

44. Saxon, A., Marrow, C., and Stevens, R. H.: Subpopulation of circulating B cells and regulatory $T$ cells involved in in vitro Immunoglobulin $\mathrm{E}$ production in atopic patients with elevated serum Immunoglobulin Europ. J. Clin. Invest., 65: 1457 (1980)

45. Schopfer, K., Baerlocher, K., Proce, P., Krech, U., Quie, P. G., and Douglas, S D.: Staphylococcal IgE antibodies, hyperimmunoglobulinemia E and Staphylococcus aureus infection. N. Engl. J. Med., 300: 835 (1979).

46. Schwartz, A., Sutton, S. L., Askenase, P. W., and Gershon, R. K.: Histamine inhibition of Conconavalin A-induced suppressor T-cell activation. Cell. Immunol., 60: 426 (1981)

47. Shou, L., Schwartz, A., Good, R. A.: Suppressor cell activity after Concanavalin A treatment of lymphocytes from normal donors. J. Exp. Med., 143: 1100 (1976).

48. Siraganian, R. P., and Hook, W. A.: Complement-induced histamine release from human basophils. J. Immunol., 116: 639 (1976).

49. Snyderman, R., Rogers, E., and Buckley, R. H.: Abnormalities of leukotaxis in atopic dermatitis. J. Allergy Clin. Immunol., 60: 121 (1977).

50. Surjan, M. and Nyerges, G.: Haemagglutination procedure for assay of tetanus antitoxin of children's sera. Z. Immunitaetsforsch. Exp. Therap., 124: 390 (1962).

51. Terasaki, P., McClelland, J. D., Park, M. S., and McCurdy, B.: Microdroplet lymphocyte cytotoxicity test. In: DHEW publications (NIH): Manual of tissue typing techniques. pp. 74-345 (Government Printing Office, Washington, DC, 1973)

52. Tung, R., Kagey-Sobotka, A., Plaut, M., and Lichtenstein, L. M.: $\mathrm{H}_{2}$ antihistamines augment antigen-induced histamine release from human basophils in vitro. J. Immunol., 129: 2113 (1982).

53. Van Scoy, R. E., Hill, H. R., Ritts, R. E., and Quie, P. G.: Familial neutrophil chemotaxis defect, recurrent bacterial infections, mucocutaneous candidiasis, and hyperimmunoglobulinemia Europ. Ann. Intern. Med., 82: 766 (1975).

54. Waldmann, T. A., Broder, S., and Krakauer, R.: Defect in IgA secretion and in IgA specific suppressor cells in patients with relative IgA deficiency. Trans. Assoc. Am. Physicians, 89: 215 (1976).

55. Weston, W. L., Humbert, J. R., August, C. S., Harnett, J., Mass, M. F., Dean, P. B., and Hagen, I. M.: A hyperimmunoglobulin E syndrome with normal chemotaxis in vitro and defective leukotaxis in vivo. J. Allergy Clin. Immunol., 59: 115 (1977).

56. Winter, H. S., Gard, S. E., Bryson, Y. J., and Stiehm, E. R.: Deficient lymphokine production of newborn lymphocytes. Pediatr. Res., (In Press).

57. The authors wish to acknowledge Dr. Yvonne J. Bryson, UCLA Medical Center, for determination of interferon production. The determination of IgG subclasses was done by Dr. William J. Yount, University of North Carolina. We also wish to acknowledge Sherrie Gard, Bonnie Ank and Francine Orner for technical assistance.

58. Requests for reprints should be addressed to: Guillermo R. Mendoza, Department of Pediatrics, UCLA Medical Center, Los Angeles, CA 90024

59. This research was supported by United States Public Health Service grants No HD-09800, AI-15332, AI-107008, and a National Foundation Grant 6-19.

60. Received for publication January 8,1982

61. Accepted for publication March 9, 1983. 